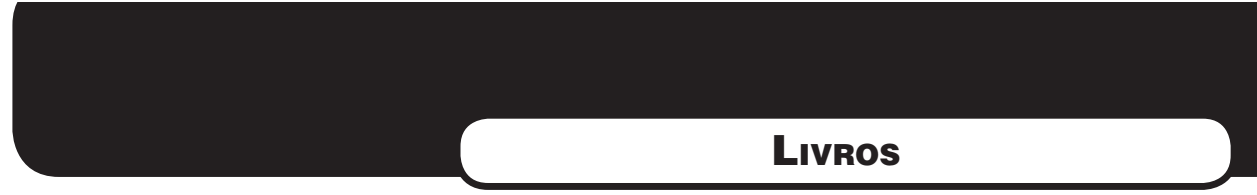

\title{
ReATORES ANAERÓbIOS
}

\section{Carlos Augusto de Lemos Chernicharo}

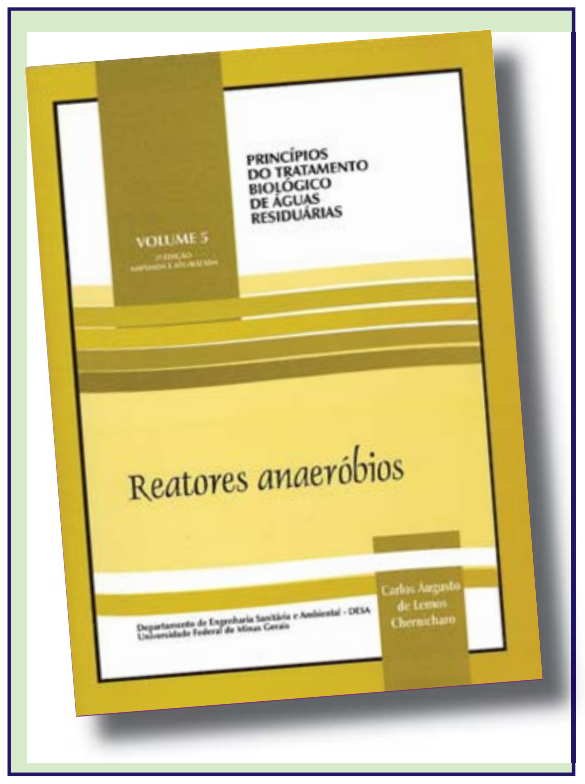

O livro de Carlos Chernicharo (leia-se Xernixaro ou Kernikaro) "Reatores Anaeróbios" tem sido lido e usado por muita gente! O quinto volume da série "Princípios do Tratamento Biológico de Águas Residuárias", publicada pela UFMG, acaba de ser lançado em $2^{\mathrm{a}}$ edição, bastante ampliada e atualizada, e tem tudo para continuar a ser um dos favoritos dos novos engenheiros anaeróbios!

Para mim foi uma tábua de salvação no dia em que o recebi em São Paulo, dia em que fiquei preso por 4 horas no triste aeroporto de Congonhas, à espera de meu vôo de retorno para o Rio. Pois nestas 4 horas pude fazer passar o tempo deliciando-me com uma escrita fácil, clara, agradável de ler, com fotos e desenhos bastante ilustrativos, mostrando detalhes que poucos livros costumam apresentar.

Como na edição anterior, os primeiros capítulos abordam os funda- mentos da digestão anaeróbia, a questão da biomassa, e uma apresentação dos principais sistemas anaeróbios de tratamento. Gasta-se aí cerca de 1/3 do livro. Esta é a parte fundamental que descreve os processos metabólicos, a atividade microbiana, e os sistemas anaeróbios. Excelente para os engenheiros civis, que, embora não confessem, conhecem pouco (ou detestam) a microbiologia e a bioquímica.

Os capítulos seguintes se dedicam especificamente aos projetos de reatores anaeróbios, controle operacional, e de sistemas de pós-tratamento. Os tanques sépticos e os filtros anaeróbios são apresentados, como já os conhecemos bem, e os reatores de manta de lodo - os UASBs - são então estudados em detalhe. E com muito detalhe: as configurações típicas, os problemas principais associados, como geração de odores, corrosão, formação de escuma, e os critérios e parâmetros de projeto. As fotos são esclarecedoras e permitem o melhor entendimento das recomendaçōes típicas de projeto, que se tornam mais claras na resolução de exemplos práticos.

A abordagem do último capítulo, sobre o pós-tratamento de reatores anaeróbios, é simples e limitada, visto que o escopo do livro é abordar os processos anaeróbios, em particular os de manta de lodo. Assim, os principais processos de tratamento são ilustrados, com alguma ênfase para aplicação no solo e filtros percoladores.

Todos sabemos que os reatores tipo UASB, em esgotos domésticos, não atendem as exigências da legislação ambiental, em geral. Valerão estas unidades como a primeira etapa de implantação de uma ETE maior, em que processos aeróbios devem seguir-se aos reatores anaeróbios. Eu diria então, que nos dias atuais não se trata mais de pensar nos UASBs com um pós-tratamento aeróbio, mas de inverter a lógica deste pensamento, e considerar os tratamentos aeróbios clássicos já precedidos de unidades anaeróbias de manta de lodo. Os UASBs constituirão assim o tratamento primário vantajoso das ETEs de lodos ativados, de lagoas aeradas, ou de filtros percoladores.

O livro é editado pela Universidade Federal de Minas Gerais, e vendido pela própria Editora UFMG e pela ABES. Sem medo, adquira este e outros bons livros sobre tratamento de esgotos.
Comentários feitos por: Eduardo Pacheco Jordão Dr. Eng. Professor Associado, Escola Politécnica Universidade Federal do Rio de Janeiro

\section{Coordenador da coluna Livgosi Prof. Gícero Onofre de Amdrade Neto}

A sessão "Livros Técnicos", que a cada edição traz resumos comentados sobre livros de interesse na área, tem como principal objetivo permitir que o leitor, de forma rápida, se atualize e conheça o que há disponível no mercado editorial. As contribuiçōes deverão ser encaminhadas para: esa@abes-dn.org.br 